\title{
Feedback Strategies in Foreign Language Reading Classes
}

\author{
Omid Tabatabaei (Corresponding author) \\ Department of English, Najafabad Branch, Islamic Azad University, Najafabad, Iran \\ E-mail: tabatabaeiomid@yahoo.com
}

Azade Banitalebi

Department of English, Najafabad Branch, Islamic Azad University, Najafabad, Iran

Received: May 22, 2011 Accepted: June 15, 2011 doi:10.5539/ach.v3n2p59

\begin{abstract}
In today's schools, reading in an L2 is a very challenging task, and it is impossible to ignore the role of feedback in optimizing reading achievement. The present study was an attempt to investigate the type of both positive and corrective feedback moves utilized by L2 teachers in L2 reading comprehension classes. The study concentrated on six different kinds of corrective feedback, namely, explicit correction, recast, clarification request, metalinguistic feedback, elicitation, and repetition, as well as four positive feedback techniques: acknowledgment, acceptance, rephrasing, and repetition. To this end, 40 participants were selected from a total population of 52 female EFL learners, aged 20-25, from an English language institute in Iran. In order to ensure the homogeneous entry behavior of the participants in terms of proficiency, the Oxford Placement Test (OPT), with reasonable measures of validity and reliability, was used to screen the students. All that happened in reading comprehension classes were audio recorded, transcribed, coded, and analyzed. To ensure about the consistency of the researchers in coding the data, the inter-coder reliability was run using Cronbach's Alpha. Statistical analysis of the results revealed that repetition was the most frequently provided positive feedback by L 2 teachers (53\%), followed by rephrasing (27\%). Regarding corrective feedback, explicit correction was the most frequent feedback technique and elicitation the second one utilized by L2 teachers ( $49 \%$ \& $19 \%$, respectively). The results of Chi-square test showed that there was a significant difference among the frequencies of the feedback types. Hopefully the findings of this research study would help L2 teachers to have a more profound understanding of what goes on in their classes.
\end{abstract}

Keywords: Corrective feedback, Feedback strategies, Metalinguistic feedback, Positive feedback, Reading

\section{Introduction}

Learning to read is one of the complicated areas of L2 development. As many teachers and parents believe, reading failure has a tremendous long-term consequence for L2 learners' developing self-confidence and motivation to learn, as well as for their later performance. In the past decade, there has been sustained interest in promoting reading as a significant and viable means of language development for second and foreign language learners (Day \& Bamford, 1998; Krashen, 1995). Bush (2003) believes that L1 acquisition occurs naturally, while SLA, in most cases, occurs under artificial conditions. It is the teachers' job to make these conditions as natural as possible and similar to language acquisition in a natural setting, so the use of reading tasks in teaching started to attract enough attention in the last few years.

Feedback is vital in all learning contexts; it is an important part of any learning process (Brawdy\& Byra, 1994; Clariana \& Koul, 2006; Slavin, 2003). L2 learners need to be given chance to see their progress before any assessment, through providing feedback. Students should be able to see the connection between the completed task and the provided feedback, or else "the informational and motivational value of feedback will be diminished" (Slavin, 2003, p.353), and the learners will continue to make the same errors repeatedly in future (Slavin, 2003). It is also important for learners to receive frequent feedback. Slavin (2003), states that "frequent rewards are more effective incentives than one large, infrequent ones" (pp.353-354). He suggested that learners will perform better if they are assessed more frequently and with shorter assessments, and they will be able to see the connection to the feedback being offered (Slavin, 2003). Therefore, it is not possible to ignore the role of feedback in optimizing reading achievement. It is unfortunate that the majority of the research literature in 
existence today reflects studies of the impact of different types of feedback; they ignore what feedback strategies learners receive in reading comprehension classes.

SLA research on feedback reveals that teachers have a wide variety of strategies available for the treatment of students' errors, (Seedhouse, 1997). Feedback strategies can be both positive and corrective. Regarding positive feedback, the interesting point is determining what the teacher does after the student provides a correct answer. Based on Ferreira, Moore, and Mellish (2007), positive feedback can be in the form of: acknowledgement, acceptance, repetition, and rephrasing. In Chaudron's view (1997), the term corrective feedback, that is, treatment of error may simply refer to any teacher behavior following an error that minimally attempts to inform the learner of the fact of error. Lyster and Ranta (1997) identified six feedback types in language teaching: explicit correction, recast, clarification requests, metalinguistic Feedback, elicitation, and repetition.

The purpose of the current research is, therefore, to investigate the most frequent feedback strategies used by Iranian EFL teachers in their reading comprehension classes in an Iranian language institute.

\section{Literature Review}

\subsection{Feedback}

The significance of feedback in language learning has a long history, and during this history different scholars defined feedback differently. There appears to be a common agreement among researchers (e.g., Kozma \& Bagert-Drowns, 1987; Kulhavy, 1977; Mason \& Burning, 2000) on the definition of feedback in general and the conditions under which it can be effective in terms of student learning. Based on Pica (1994, cited in Tabatabaei $\&$ Birjandi, 2009) feedback is the information that learners receive about their language production, and gives them the opportunity to modify their output. Feedback can be either positive, demonstrating comprehension of the learner's language, or it can be negative, pointing out to the learner what was non-target like about his or her utterance. Feedback can be provided either implicitly, for example by demonstrating a lack of understanding of a learner's utterance, or explicitly, by telling the learner what was non-target like about his or her utterance.

\subsubsection{Positive and Corrective Feedback Strategies}

Positive feedback can be divided in to four categories (Ferreira, Moore, \& Mellish, 2007):

1). Acknowledgement: It refers to any verbal or non-verbal signal the teacher uses to show the learners that he or she is listening and understanding. It can be realized by 'wow', 'mm', 'cor' and certain non-verbal gestures and expressions (Sinclair \& Coulthard, 1992).

2). Acceptance: It is realized by a closed class of items like 'yes', 'good', and 'fine', all with neutral low fall intonation. Its function is to show the learners that the teacher has heard or seen and the provided reply by the learners was appropriate (Sinclair \& Coulthard, 1992).

3). Repetition: Ellis (1997) defines repetition as a kind of positive feedback in which "the teacher repeats the student's correct answer. For example, student: 'club de jóvenes' (youth club); tutor: 'club de jóvenes' (youth club)" (cited in Ferreira, Moore, \& Mellish, 2007, p. 391).

4). Rephrasing: Ellis (1997) defines rephrasing as a positive feedback in which "the teacher accepts the student's answer but aims to expand the student's knowledge, to polish the utterance structure, or to show a new structure which rephrases the answer given by the student using different words, and in some cases, adds new information." (cited in Ferreira, Moore, \& Mellish, 2007, p. 391).

Corrective feedback is divided into six categories (Lyster \& Ranta, 1997):

1). Explicit correction: According to Lyster and Ranta (1997), explicit correction is "any feedback technique that involves a teacher simply providing a student with the correct answer" (pp. 46-49).

2). Recast: According to Lyster and Ranta (1997), recast is defined as "a more implicit feedback technique that involves the teacher's reformulation of all or part of a student's utterance, minus the error" (pp. 46-49).

3). Clarification request: According to Lyster and Ranta (1997), clarification request is a "feedback type in which the teacher asks a question indicating to the student that there is a problem with the language utterance" (pp. 46-49).

4). Repetition: According to Lyster and Ranta (1997), repetition is "the type of the feedback that involves a teacher repeating wrong utterance highlighting it with intonation" (pp. 46-49).

5). Metalinguistic feedback: According to Lyster and Ranta (1997), metalinguistic feedback "involves a teacher making comments or indicating to the student that there is an error in the language output (e.g., Can you find an error?)" (pp. 46-49). 
6). Elicitation: Lyster and Ranta (1997), defines elicitation as "a feedback type when teachers ask for completion of their own sentence by pausing and allowing students to correct themselves; they may also ask questions to elicit correct form and help students to reformulate an ill-formed utterance" (pp. 46-49).

\subsection{Observational Studies on Feedback in SLA}

Ferreira, Moore and Mellish (2007) investigated the type and frequency of different feedback moves through collecting a corpus of classroom interactions in Spanish as Foreign Language. They concentrated on both positive and negative feedback strategies. In the domain of negative feedback, they focused on two general kinds: (1) Giving- Answer Strategies (GAS), where the teacher directly gives the correct answer. These include: repetition, recast, explicit correction, and give answer strategy. (2) Prompting- Answer Strategies (PAS), where the teacher directly makes the students notice and repair their own errors. This group includes: metalinguistic cues, clarification requests, and elicitation. Dealing with positive feedback strategies, the findings of the study showed that repetition and rephrasing was used about $40 \%$ of the time, acknowledgement and acceptance about $30 \%$ of the time. In the case of negative feedback strategies, GAS was much more frequent than PAS, teachers preferred to handle the students' errors by giving the location of the error or providing the target form. But the proportion of repairs after PAS was higher than that after GAS. The results indicated that PAS were more effective than GAS in eliciting repair for the errors. Despite this, teachers used GAS more than PAS.

Panova and Lyster (2002) through conducting an observational study in an early-intermediate adult ESL classroom in Quebec, found like Lyster and Ranta(1997), that recasts were the most common type of corrective feedback used by the teachers. Also similar to Lyster and Ranta (1997), they found that recasts led to the lower uptake rates and repair rates than most other types of feedback. Panova and Lyster (2002) concluded that recasts for the low level students may not be viewed as corrective in nature and provide learners with negative evidence.

Lyster (1998) conducted another observational study to investigate different types of corrective feedback, types of errors, and levels of uptake in four French Immersion classrooms (grade 4 and grade 5). He found that $61 \%$ of students' errors received some type of corrective feedback from the teacher. Phonological and grammatical errors were mostly followed by recasts $64 \%$ and $72 \%$ of the time. Following lexical errors, negotiation of form was the most frequent type of feedback (55\%). Lyster (1998) also mentioned, for phonological errors, uptake occurred most often following recasts. For lexical and grammatical errors, uptake was mostly following negotiation of form. He concluded although recasts were not effective for lexical and grammatical errors, they were effective for phonological errors.

\subsection{Studies on Feedback and Reading}

Murphy (2007) tried to investigate the influence of type of feedback and manner of study, whether individual or pair work, on the performance of students on exercises follow up reading comprehension. Students were randomly selected from upper and lower levels of English proficiency, to receive either elaborative feedback or knowledge of correct response feedback, which supplies the correct answer. Research was conducted into identifying the type of errors student made in response to multiple-choice comprehension questions about a reading text and how students changed their answers when receiving elaborative feedback. The results of the study showed that there is a significant interaction between the types of feedback and manner of study (individual or pair work); students performed best on a follow up comprehension exercises when worked in pairs and having been provided with elaborative feedback and scored higher than those who worked individually.

Samuels and $\mathrm{Wu}$ (2001) evaluated the effects of immediate versus delayed feedback on sentence and passage comprehension, as well as reading speed. Sixty-seven students in third and fifth grades participated in this study for nearly six months. The students were chosen from low, moderate and high reading ability levels. The researcher found that students in the immediate feedback condition performed significantly superior on measures of passage comprehension and composite comprehension. The students who were in low level gain higher scores than the other two groups on sentence and composite comprehension, while the moderate group had the greatest gain score in speed of reading compared to the other two groups.

Bown (2004) examined the usefulness of guided feedback in a web-based reading program for Arab learners. The study was mainly concerned with, whether or not guided feedback in web based reading materials was influential for students at Ras Alkhaimah Men's College. The results showed that the overall performance of those who received guided feedback was mostly superior to those who received correct or incorrect feedback, and suggested that guided feedback improved the learners' comprehension of the texts. 


\section{Statement of the Problem}

Researchers such as Dekeyser (1993), Brooks, Schraw and Crippen (2002), Mason and Burning (2000), in their studies indicated that feedback plays an important role in L2 acquisition. L2 Learners use the provided feedback to test and modify their hypotheses about the target language. Preceding studies (Peterson, 2003; Zhang, Zhang, \& Ma, 2010 ), to the researcher's best knowledge, were mostly interested in determining the kind of feedback which was more effective in productive skills such as: writing and speaking and there are a few studies dealing with feedback strategies L2 teachers use in their reading comprehension classes. As it is obvious, foreign language learners do not have enough L2 exposure outside the classroom and the input they receive is through reading comprehension, so reading comprehension can be considered as a vital skill. Some researchers believe that in English the relationship between sounds and letters is more complicated than other languages like, Finnish, Greek or German, so learning to read in English is particularly problematic (Harris \& Hitano, 1999).The process of learning to read is difficult for some learners as sound/letter relationships are blurred by a degree of sound overlap. Through providing feedback for learners, reading difficulties are intended to be eradicated.

Furthermore, because much of the work in L2 is based on empirical work in school classrooms, the aim of this study is to investigate the most frequent types of corrective and positive feedback strategies L2 learners receive in reading comprehension classes of an Iranian Language institute.

\section{Research Questions}

Based upon the afore-mentioned discussions that reading is one of the most important skills to be learned by L2 learners, and the role played by feedback in SLA, this study aimed to investigate the feedback strategies teachers use in their reading comprehension classes. Therefore, the followings research questions have been posed:

1). What are the most frequent types of positive feedback strategies utilized by Iranian teachers in reading comprehension classes after a correct answer is provided by L2 learners?

2). What are the most frequent types of corrective feedback strategies utilized by Iranian teachers in reading comprehension classes after students commit errors?

\section{Research Hypotheses}

To investigate appropriate answers to the research questions of the present study, the following two null hypotheses have been addressed:

- $\mathrm{H}_{01}$ : There is no frequently-provided positive feedback by L2 teachers in reading comprehension classes.

- $\mathrm{H}_{02}$ : There is no frequently-provided corrective feedback by $\mathrm{L} 2$ teachers in reading comprehension classes.

\section{Method}

\subsection{Participants}

Primarily, a group of 52 EFL learners who were all Persian native speakers participated in this study. They were studying English in one of Iran's Language Institutes. In order to homogenize the participants an Oxford Placement Test (OPT) was run (Allen, 1992). After the completion of this test 40 of the whole population of 52 were selected based on their mean scores and standard deviations.

\subsection{Materials}

\subsubsection{Oxford Placement Test}

The materials used in this study included Oxford Placement Test (OPT), for selecting a group of homogenous participants (Allen, 1992). The OPT consists of two test pads with 100 questions in the listening and 100 more questions in the grammar section. The grammar test pad was used for identifying the students' level of proficiency, that is, the first 100 questions in the grammar test pad. Allen (1992), the developer of this test, claims that the OPT is capable of being utilized with any number of students of English to ensure efficient, reliable and accurate grading and placing of students into classes at all levels from elementary to advance.

\subsubsection{Feedback strategies checklist}

In order to find the most frequently used types of positive and corrective feedback, the researcher recorded the interactions in reading comprehension classes and coded them based on a prepared checklist with two sub-scales. The first sub-scale has to do with positive feedback strategies designed according to Ferreira, Moore, and Mellish's (2007) categorization of positive feedback strategies, and the second one with corrective feedback 
techniques prepared according to Lyster and Ranta's (1997) categorization of corrective feedback strategies (see Table.1). According to Gass and Mackey (2005), to rely more on the data derived in the research, multiple sources and techniques, called triangulation, were used to have more confidence about the findings. Doing so, the same checklist which was used for coding the transcriptions, was also used during the observations.

\subsection{Procedure}

To collect the data, first, the OPT was given to $52 \mathrm{~L} 2$ learners. Their mean scores and standard deviations were used to select a homogenous intermediate sample of L2 learners. In order to investigate feedback techniques used by L2 teachers in reading comprehension classes, these learners were observed while attending the class. Each observation lasted for nearly forty minutes, totally 160 minutes. The observer who was the researcher, did not have any interference in the classroom process or discourse, merely sitting, observing, writing, and audio recording. All that happened in the reading comprehension classes were audio recorded to be transcribed and coded later. In order to ensure the inter-rater reliability of the data, $25 \%$ of the data was selected and coded by another graduate student based on a prepared checklist. The correlation was computed, there was a high correlation between the coding of the first and the second rater. The inter-rater reliability was $(r=0.97, p=.000)$. As the correlation was high, the researcher herself coded the remaining transcriptions.

\subsubsection{Transcription and Coding Procedure}

The following coding system was used in transcribing and analyzing the data:

- CF for Corrective Feedback

- CF1 for Explicit correction

- CF2 for Recast

- CF3 for Clarification Request

- CF4 for Metalinguistic Feedback

- CF5 for Elicitation

- PF for Positive Feedback

- PF1 for Acceptance

- $\quad$ PF2 for Rephrasing

- PF3 for Repetition

- PF4 for Acknowledgement

- $\mathrm{T}$ for Teacher

- $\mathrm{S}_{1}, \mathrm{~S}_{2}, \ldots$, for single and different students

Episode 1

$\mathrm{T}$ : what is this reading about?

S1: It is about Islands that are going to destroy.

(CF1) T: going to be destroyed.

Episode 2

$\mathrm{T}$ : What happened for Lisa?

S3: She goes to the store and asked for a cold drink.

(CF4) T: It should be in the past.

S3: She went to the store.

Episode 3

S1: What did he do at them reactions?

(CF2) T: What did he do, when he saw their reactions?

Episode 4

$\mathrm{T}$ : What is the meaning of release?

S1: Let's go. 
(CF3) T: What do you mean?

S1: Set free.

Episode 5

$\mathrm{T}$ : What does threat mean?

S1: be in danger.

(PF3) T: be in danger.

Episode 6

$\mathrm{T}$ : What is the meaning of rephrase?

S3: say something with different words.

(PF2)T: Exactly, when you paraphrase something you have the same meaning but you put it in another way.

Episode 7

$\mathrm{T}$ : What is capsicum?

S1: pepper.

(PF1) T: Yeah, that's right.

Episode 8

T: Why can be living in a foreign country confusing? What are the reasons?

S1: Because you maybe cannot understand the body language or the response in that language.

(PF4) T: Uhum.

\section{Data Analysis}

In order to answer the first research question, the frequency of different types of positive feedback given by L2 teachers to L2 learners when they answered correctly in reading comprehension classes was computed. The results are shown in Table 2(see list of Tables).

As Table 2 shows, repetition is the most frequently provided positive feedback by L2 teachers (53.3\%), followed by rephrasing $(27.2 \%)$. These two feedback types accounted for about $80 \%$ of the total positive feedback given by L2 teachers. The total frequency for acceptance and acknowledgment were about $20 \%$.

As Figure 1 (see list of Figures) shows, the frequency of repetition is more than the other positive feedback techniques (53.3\%), followed by Rephrasing (27.2\%). Acceptance is used less than other feedback types (8.7\%).

Chi-Square Test was run to test the first hypothesis and to see whether there was a significant difference among the frequencies of different positive feedback techniques. As shown in Table 3 and Table 4( see list of Tables), there was a significant discrepancy among the number of different positive feedback $(\chi 2=46.69, d f=3, p<$ $0.05)$. As residual count indicates, repetition is the most frequently used positive feedback (26.0), and acceptance is the least used positive feedback type (-15.0). Therefore, the first hypothesis is rejected.

To shed light on the second research question, the frequency of different types of corrective feedback were determined. The results are shown in Table 5 (see list of Tables ).

As shown in Table 5, explicit correction was the most frequently used corrective feedback type by teachers (49\%), out of 77 given corrective feedback 38 were in the form of explicit correction. Elicitation was used about $(19.5 \%)$ of the time, the other three feedback types: recast, metalinguistic feedback, and clarification request were used about $(31.2 \%)$ of the time. Repetition as one of corrective feedback types was not used by any teachers while correcting L2 learners' errors, although, repetition as a kind of positive feedback was the most frequently provided positive feedback.

As Figure 2 shows (see list of Figures), the frequency of explicit correction is more than the other kinds of corrective feedback (49.4\%), followed by elicitation (19.5\%). Clarification request is used less than other kinds of corrective feedback $(6.5 \%)$.

For testing the second hypotheses, Chi-Square test was run; to see whether the difference among different types of corrective feedback is significant or not. The results are shown in Table 6, and 7(see list of Tables). 
As shown in Table 7, there is a significant difference among the frequencies of different corrective feedback $(\chi 2$ $=44.753, d f=4, p<0.05$ ). Thus, the second hypothesis is rejected at $p<0.05$. As residual count shows explicit correction was used more frequently than other corrective feedback techniques (22.6).

\section{Discussion}

The previous section presented the analysis and results for each research question. This section compares and contrasts those results with those of similar studies conducted by other researchers (Lyster \& Ranta, 1997; Ferreira, Moore, \& Mellish, 2007) in the area of positive and corrective feedback provision and in terms of the data itself. These studies have been chosen for the discussion because the research design and the data analysis were similar to those of this study and provided the most comprehensive basis for comparison.

The findings of this study showed that repetition was the most frequently provided positive feedback in reading comprehension classes, and this finding corresponded with Ferreira, Moore, and Mellish's findings (2007); they found that repetition was used more than other positive feedback techniques $(33 \%)$. The reason may be due to the fact that teachers want to increase L2 learners' exposure to the target language, as Krashen (1982) states comprehensible input is the only causative variable in SLA. In his input hypothesis, he asserts input could simply be exposure to the correct forms of the target language.

Regarding Corrective Feedback related to the second research question, the results showed that explicit correction (49\%) was the first most frequently provided corrective feedback by L2 teachers in reading comprehension classes. This finding is in contrast with Lyster and Ranta (1997), and McNulty's findings (2007), in their studies they found that recast was the first most frequently used corrective feedback by L2 teachers $(32 \%)$, while in this study recast was the third frequently provided corrective feedback. Ferreira, Moore, and Mellish (2007), in a study found explicit correction as the most frequent feedback technique at the advanced level, but not at the intermediate level. They also stated; although explicit correction was used more frequently in advanced levels it led to higher rate of repair at the intermediate level. One possible reason for this contrast may be due to the learners' level of proficiency, as Lyster and Ranta (1997) argue, learners' level of proficiency is an important factor the teachers should take into consideration while providing feedback. Sometimes the learners may not have the required knowledge to correct themselves; therefore, the teachers may use more modeling techniques such as explicit correction. The other reason can be related to the nature of errors, whether they were grammar, vocabulary, or pronunciation errors, as teachers would use different feedback strategies in relation to different errors. Sometimes the focus of the classroom may influence the choice of feedback techniques, when the focus of the classroom is on communication; teachers try to maintain the flow of the conversation, so they try to provide learners with the target forms rather than encouraging them to correct themselves which may interrupt the flow of the conversation. Some teachers prefer to directly draw the learners' attention to the incorrect forms they have made, hence they use explicit correction more often.

Elicitation (19\%) was the second most frequently provided corrective feedback, which was in line with Lyster and Ranta's finding (1997), according to Lyster and Ranta it was the only feedback which led to uptake in 100\% cases. If no feedback responses were eliminated from McNulty's (2007) research, then Elicitation would be the second most frequent feedback type, like what was found in this study.

In McNulty's research (2007), repetition was the least provided corrective feedback (1\%) and the findings of this study showed that repetition was not used by any L2 teachers at all, so both studies reached similar conclusions in some way, although, the results of McNulty's (2007) research showed repetition was the most successful feedback technique in terms of repair. The reason for this result is that L2 teachers in both studies did not use repetition as they did not want to expose learners to the ill-formed language.

Metalinguistic feedback was used infrequently (12\%), and the low occurrence of it may be attributed to the fact that, it is more effective for beginning and advanced students and less for intermediate learners as Ferreira, Moore, and Mellish (2007) claimed. All in all, L2 teachers used a balanced approach in their classrooms; it means they utilized all kinds of feedback techniques in their classrooms, which is in line with Lyster and Ranta's (1997) suggestion, that teachers should use other kinds of feedback in addition to recast.

\section{Implications}

Teachers can promote the acquisition of reading skills, through providing feedback, because feedback has been found to be an important aspect of supporting reading practices. Corrective feedback leads L2 learners to notice the inconsistency between their utterances and the target language (TL) forms, and efficiently replace the rejected inter-language form with a TL form. 
According to Chaudron (1988), feedback provides learners with information which helps them to whether confirm, disconfirm or change their hypothetical rules of their developing grammars. These effects; however, depend on the learners' readiness to notice the information available in feedback. Schachter (1991) pointed out that, it is corrective feedback which made L2 learners change their wrong hypotheses, and formulate new ones. The results of this study might change the perspectives of L2 teachers, to have a deeper look at the concept of feedback techniques they use in reading comprehension classes, and it may be beneficial in helping teachers to be aware of what goes on in their classes. This type of research can be significant as a way for improving teaching efficiency, especially if the findings are to be used by L2 teachers (Wragg, 1994).

\section{References}

Allen, P. (1992). Aspects of classroom treatment: Toward a more comprehensive view of second language education. In B. Harley, P. Allen, J. Cummins, \& M. Swain (Eds.), The development of second language proficiency (pp. 57-81). New York: Cambridge University Press.

Birjandi, P., \& Tabatabaei, O. (2009). The impact of gender on the incidence and quality of form-focused episodes in Task-Based conversational feedback among EFL learners. Asian EFL Journal, 11(4), 220-240.

Bown, A. (2004). The usefulness of guided feedback in a web-based IELTS reading programme for Arab learners. Unpublished master's thesis, The University of Manchester, England.

Brawdy, P., \& Byra, M. (1994). A comparison of two supervisory models in preservice teaching practicum. Paper presented at the Annual Meeting of the American Educational Research Association, New Orleans, Louisiana.

Brooks, D. W., Schraw, G. P., \& Crippen K. J. (2002). Performance-related feedback: The hallmark of efficient instruction. [Online] Available: http://dwb4.unl.edu/dwb/Research/JCE-2002-0504.pdf (July 15, 2007).

Bush, H. (2003). Computer based readers for intermediate foreign-language students. Educational Media International, 40(3\&4), 227-285.

Chaudron, C. (1977). The effects of feedback on students' composition revisions. RELC Journal, 15(2), 1-15.

Chaudron, C. (1988). Second language classrooms: Research on teaching and learning. Cambridge University Press.

Clariana, R. B., \& Koul, R. (2006). The effects of different forms of feedback on fuzzy and verbatim memory of science principles. British Journal of Educational Psychology. 76, 259-270.

Day, R. R., \& Bamford, J. (1998). Extensive reading in the second language classroom. Cambridge: Cambridge University Press.

Dekeyser, R. M. (1993). The effect of error correction on L2 grammar knowledge and oral proficiency. Modern Language Journal, 77(4), 501-514.

Ellis, R. (1997). Teaching and Research: Options in grammar teaching. TESOL Quarterly, 32, 39-60.

Ferreira, A., Moore, J.D., \& Mellish, Ch. (2007). A study of feedback strategies in foreign language classrooms and tutorials with implications for intelligent computer-assisted language learning systems. International Journal of Artificial Intelligence in Education, 17, 389-422

Gass, S. \& Mackay, A. (2005). Second language research: Methodology and design. USA: Lawrence Erlbaum Associates, Inc.

Harris, M., \& Hitano, G. (Eds.). (1999). Learning to read and write: A cross-linguistic perspective. Cambridge University Press.

Kozma, R. B., \& Bangert-Drowns, R. L. (1987). Design in context: A conceptual framework for the study of computer software in higher education. Ann Arbor, Michigan: The University of Michigan, National Center for Research to Improve Postsecondary Teaching and Learning. (ERIC Document Reproduction Service No. 287 436).

Krashen, S. (1995). Free voluntary reading: Linguistic and affective arguments and some new applications. In F. Eckman, D. Highland, P. Lee, J. Mileham \& R. Weber (Eds.), Second language acquisition theory and pedagogy (pp. 187-202). Mahwah, NJ: Lawrence Erlbaum Associates.

Kulhavy, R. W. (1977). Feedback in written instruction. Review of Educational Research, 47(2), 211-232.

Lyster, R. (1998). Negotiation of form, recasts, and explicit correction in relation to error types and learner repair in immersion classrooms. Language Learning, 48, 183-218. 
Lyster, R., \& Panova, I. (2002). Patterns of corrective feedback and uptake in an adult ESL classroom. TESOL Quarterly, 36, 573-595.

Lyster, R., \& Ranta, L. (1997). Corrective Feedback and Learner Uptake: Negotiation of form in communicative classrooms. Studies in second language acquisition, 19(1), 37-66.

Mason, B. J., \& Bruning, R. (2000). Providing feedback in computer-based instruction: What the research tells us. [Online] Available: http://dwb.unl.edu/Edit/MB/MasonBruning.html (July 15, 2005).

McNulty, A. S. (2007). A study of corrective feedback and uptake patterns as observed in four foreign language classrooms at selected Mid-Western public schools. Unpublished doctoral dissertation, the Graduate College at the University of Nebraska, Lincoln.

Murphy, Ph. (2007). Reading comprehension exercises online: the effects of feedback, proficiency, and interaction. Language Learning and Technology, 11(3), 107-129.

Peterson, Sh. (2003). Peer response and students revisions of their narrative writing. Educational Studies in Language and Literature, 3, 239-272.

Pica, T. (1994b). Research on negotiation: What does it reveal about second language learning conditions, processes, and outcomes? Language Learning, 44, 493-527.

Samuels, S.J., \& Wu, Y. (2001). The effects of immediate feedback on reading achievement. Unpublished master's thesis, University of Minnesota.

Schachter, J. (1991). Corrective feedback in historical perspective. Second Language Research, 7, 89-102.

Seedhouse, P. (1997). The case of the missing "no": The relationship between pedagogy and interaction. Language Learning, 47, 547-583.

Sinclair, J., \& Coulthard, M. (1992). Toward an analysis of discourse. In M. Coulthard (Ed.), Advances in spoken discourse analysis (pp. 1-34). London: Routledge.

Slavin, R. E. (2003). Educational psychology: Theory and practice ( $7^{\text {th }}$ ed.). Boston: Pearson Education, Inc.

Wragg, E. C. (1994). An introduction to classroom observation. London and New York: Routledge.

Zhang, Y., Zhang, L., \& Ma, L. (2010). A brief analysis of corrective feedback in oral interaction. Journal of Language Teaching and Research, 1(3), 306-308.

Table 1. Feedback Strategies Checklist

\begin{tabular}{|l|l|}
\hline Positive Feedback Strategies & Frequency \\
\hline Acknowledgement & \\
\hline Acceptance & \\
\hline Repetition & \\
\hline Rephrasing & \\
\hline
\end{tabular}

\begin{tabular}{|l|l|}
\hline Corrective Feedback Strategies & Frequency \\
\hline Explicit Correction & \\
\hline Repetition & \\
\hline Recast & \\
\hline Metalinguistic Feedback & \\
\hline Elicitation & \\
\hline Clarification Request & \\
\hline
\end{tabular}


Table 2. Different Positive Feedback Techniques

\begin{tabular}{|l|c|c|}
\hline Positive Feedback Techniques & No. of Occurrence & Percentage \\
\hline Repetition & 49 & 53.3 \\
\hline Rephrasing & 25 & 27.2 \\
\hline Acknowledgement & 10 & 10.9 \\
\hline Acceptance & 8 & 8.7 \\
\hline Total & 92 & 100.0 \\
\hline
\end{tabular}

Table 3. Positive Feedback Techniques

\begin{tabular}{|l|c|c|c|}
\hline $\begin{array}{l}\text { Positive Feedback } \\
\text { Techniques }\end{array}$ & Observed N & Expected N & Residual \\
\hline Repetition & 49 & 23.0 & 26.0 \\
\hline Rephrasing & 25 & 23.0 & 2.0 \\
\hline Acknowledgement & 10 & 23.0 & -13.0 \\
\hline Acceptance & 8 & 23.0 & -15.0 \\
\hline Total & 92 & & \\
\hline
\end{tabular}

Table 4. The Results of Chi-Square Test for Different Positive Feedback Types

\begin{tabular}{|l|l|}
\hline & Positive Feedback \\
\hline Chi-Square & 46.696 \\
df & 3 \\
Asymp. Sig. & .000 \\
\hline
\end{tabular}

a. 0 cells $(.0 \%)$ have expected frequencies less than 5 .

The minimum expected cell frequency is 23.0.

Table 5. Different Corrective Feedback Techniques

\begin{tabular}{|l|l|c|c|c|}
\hline \multicolumn{2}{|l|}{ Corrective Feedback } & Frequency & Percent & Valid Percent \\
\hline Valid & Explicit Correction & 38 & 41.3 & 49.4 \\
\cline { 2 - 5 } & Elicitation & 15 & 16.3 & 19.5 \\
\cline { 2 - 5 } & Recast & 10 & 10.9 & 13.0 \\
\cline { 2 - 5 } & Metalinguistic Feedback & 9 & 9.8 & 11.7 \\
\cline { 2 - 5 } & Clarification Request & 5 & 5.4 & 6.5 \\
\cline { 2 - 5 } & Total & 77 & 83.7 & 100.0 \\
\hline Missing & System & 15 & 16.3 & \\
\hline Total & & 92 & 100.0 & \\
\hline
\end{tabular}


Table 6. Corrective Feedback Techniques

\begin{tabular}{|l|c|c|c|}
\hline $\begin{array}{l}\text { Corrective Feedback } \\
\text { Techniques }\end{array}$ & Observed N & Expected N & Residual \\
\hline Explicit Correction & 38 & 15.4 & 22.6 \\
\hline Elicitation & 15 & 15.4 & -4 \\
\hline Recast & 10 & 15.4 & -5.4 \\
\hline Metalinguistic Feedback & 9 & 15.4 & -6.4 \\
\hline Clarification Request & 5 & 15.4 & -10.4 \\
\hline Total & 77 & & \\
\hline
\end{tabular}

Table 7. The Results of Chi-square Test for Different Corrective Feedback types

\begin{tabular}{|l|l|}
\hline & Corrective Feedback \\
\hline Chi-Square & 44.753 \\
df & 4 \\
Asymp. Sig. & .000 \\
\hline
\end{tabular}

a. 0 cells $(.0 \%)$ have expected frequencies less than 5 .

The minimum expected cell frequency is 15.4 .

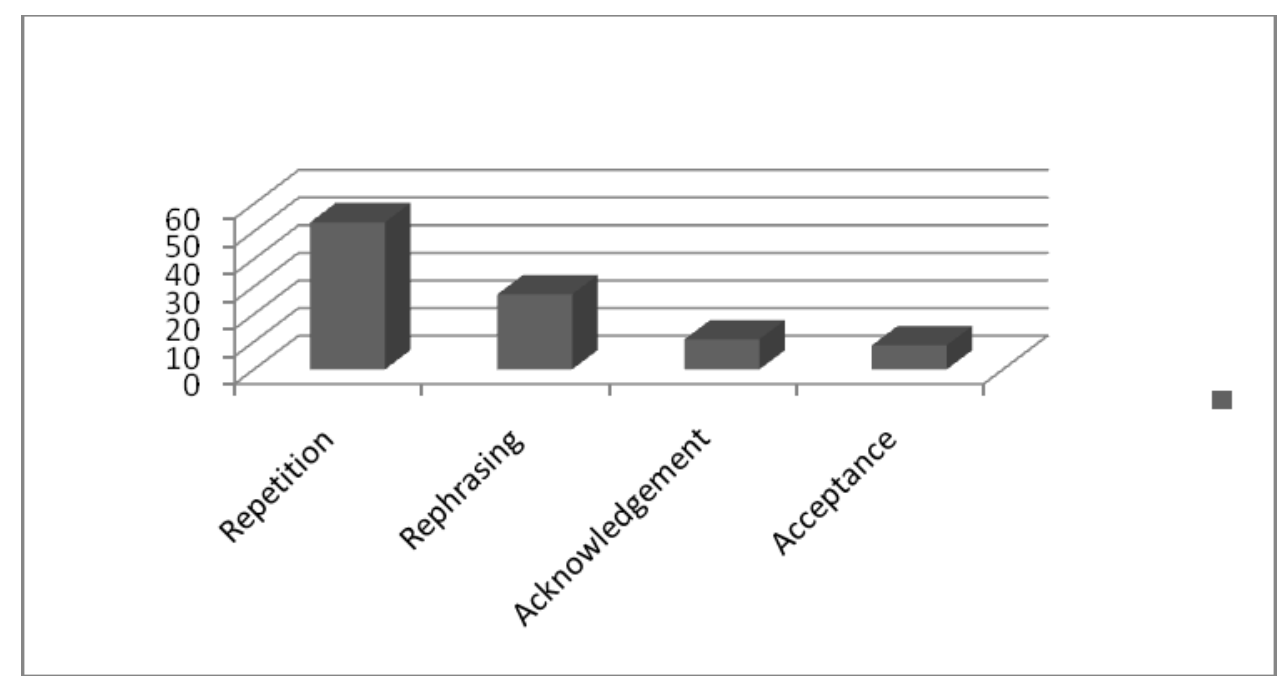

Figure 1. Frequency of Positive Feedback 


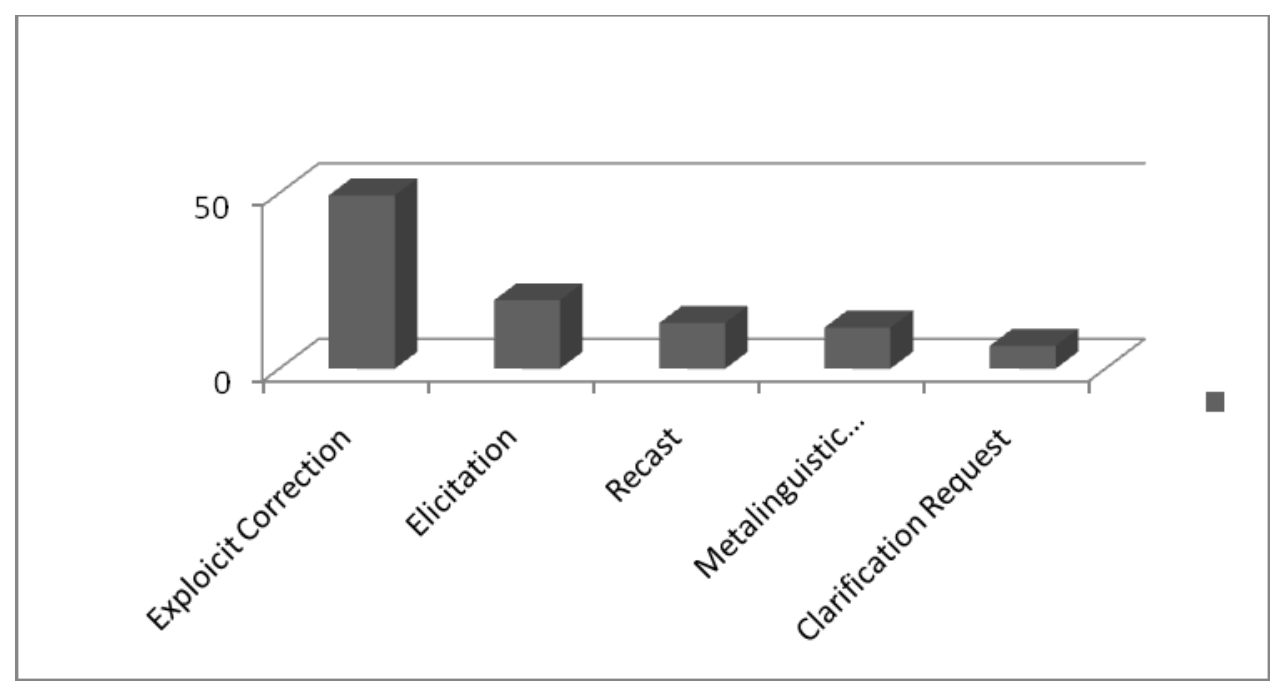

Figure 2. Frequency of corrective feedback techniques 